Pakistan Journal of Humanities and Social Sciences

January - March 2019, Volume 7, No. 1, Pages 15 - 30

\title{
Legitimacy of Right to Self-Determination Under International Law
}

\author{
Sardar M. A. Waqar Khan Arif ${ }^{1}$ \\ ${ }^{1}$ Head of Department, Department of Law, University of Kotli Azad Jammu and Kashmir, \\ Pakistan \& PhD Candidate, IIUI Pakistan-cum-Rijks Universiteit Groningen, The Netherlands \\ Email: sardarwaqarkhan@gmail.com
}

\begin{abstract}
The term self-determination refers to process by which people determine their political status. It is well established that right to self-determination (RSD) is available to all and based on its historical and conceptual evolution, its status amounts to jus cogens or obligations erga omes. In other words, it is a part of customary international law (CIL). While exercising selfdetermination, people may freely determine their legal and political status vis-a-vis free to pursue economic, social and cultural (ESC) development by virtue of that right. The important milestones for defining and recognizing RSD are (i) the International Covenant on civil and political rights (ICCPR), 1966 and (ii) the International Covenant on economic, social and cultural rights (ICESR), 1966 which defines RSD. In terms of RSD's implementation, there exist certain hurdles and impediments which lead to non-exercise of this right. In this context, this article focuses on legitimacy and various paradoxes of RSD under International law. It analyses its scope, binding nature and legal status with reference to the occupied people in an occupied territory. It discusses different views in relation to its applicability. The argument developed throughout the article is that by virtue of recognition of $R S D$, in general, international community may implement RSD of those who are denied so far and ensure its availability to all in practical terms. In particular, such right may be implemented in occupied territories by means of referendum or plebiscite under auspices of the United Nations (UN) for securing rights of those who are struggling since decades. It concludes that, by virtue of implementation and enforcement of RSD in all jurisdictions, universal lasting peace can be established and international security can be ensured.
\end{abstract}

Keywords: Self-Determination, International law, Hurdles to Self-Determination, Occupation, Human Rights 


\section{Introduction}

Self-determination is an important concept for states and peoples because its realization is prerequisite for protection of fundamental human rights. It is also important for promotion and implementation of norms of International law. It is because self-determination is recognized by international community and International Court of Justice (ICJ). The debates over self-determination were started in 1960 when the UN Resolution was adopted. However, self-determination derives its legitimacy from the UN Charter. The international bill of rights also protects this right in letter and spirit. Along with these instruments other Resolutions are also adopted by International bodies. In this context, this article aims to address paradoxes and dimensions of RSD by analyzing the legal framework on the subject.

This article is divided into V sections. Section I assesses scope of RSD in order to understand its nature and to create a context for further discussion. Section II analyses the legal framework of RSD. Under what instruments or Resolutions it is recognized? Section III discusses self-determination as a norm of Jus Cogens or preemptory norm with linkage to its application in the case of oppression. Section IV focuses on RSD and upholding human rights in times of occupation. To that end, it also analyses that do state use force in breach of selfdetermination? Looking into diversity of opinion of Scholars, section V analyses that who is entitled to exercise RSD? Finally, conclusions will be drawn up. .

\section{Right to Self-determination and its scope}

The basic structure of self-determination is grounded in the UN Charter itself. The right to self-determination is considered as core purpose of the UN. It derives its authenticity from article 1 of the UN Charter. ${ }^{1}$ Article 55 and 56 also referenced to it. Along with the UN Charter, it is expressly grounded in two covenants. ${ }^{2}$ In Covenants, the principle is regarded as substantive because individuals also fall in this category and have rights. ${ }^{3}$ However, the Human rights Committee (HRC) considered that article 1 of covenants is non-justiciable

\footnotetext{
${ }^{1}$ Article 1(2) of the Charter of the United Nations, (1945).

${ }^{2}$ These are: (i) International Covenant on Civil and Political Rights (ICCPR), adopted 16 December, (1966) and entered into force 23 March, (1976); and (ii) International Covenant on Economic, Social and Cultural Rights (ICESCR), adopted on 19 December, (1966) and entered into force on 3 January, (1976). The optional Protocol is adopted on 16 December, (1966) and entered into force 23 March, (1976).

${ }^{3}$ Sarah Joseph, Jenny Schultz and Melissa Castan, The International Covenant on Civil and Political Rights: Cases, Materials, and Commentary, Oxford University press, (2000), p9.
} 
under First optional protocol. The reason provided by the committee is that "protocol deals with collective rights whereas the committee has jurisdiction over individual submissions".

Self-determination can also be linked with doctrine of non-intervention. Article 2(7) of the Charter propounds doctrine of non-intervention. It is also reiterated and affirmed by the United Nations General Assembly (UNGA) Resolution 2131 (XX) which states that: "Every State has an inalienable right to choose its political, economic, social and cultural systems, without interference in any form by another State [...]. All States shall respect the right of self-determination and independence of peoples and nations, to be freely exercised without any foreign pressure $[\ldots]^{\prime \prime 5}$

Thus it is clear that states are obliged to respect RSD of people and refrain from interference with other states for realization of this right. This doctrine also applies to those groups who are contesting for self-determination that interference in the affairs of other states is prohibited. The ICJ has considered self-determination as an erga omnes obligation. ${ }^{6}$ This obligation entails that states may exercise limited countermeasures against enemy states or in the case of breach of the principle of self-determination. However, the legality or illegality of the action of states varies from case to case. ${ }^{7}$

\section{Legal framework on Self-determination}

\section{A. The UN Charter, (1945)}

The UN Charter protects human rights and fundamental freedoms of all people irrespective of their nationality, caste, religion, language and caste. Article 1(2) of the UN charter states that: "To develop friendly relations among nations based on respect for the principle of equal rights and self-determination of peoples, and to take other appropriate measures to strengthen universal peace." Thus self-determination is inherent and states have obligations to ensure its implementation. The other important document after the UN Charter is the "Declaration on the Granting of Independence to Colonial Territories and Peoples", (1960). It declares that: "subjugation, domination and exploitation of peoples constitutes a denial of human rights and is contrary to the United Nations Charter". However, "this

\footnotetext{
${ }^{4}$ Kitok vs. Sweden Communication No: 197/1985, by the HRC on 10 August, (1988), the United Nations Doc. CCPR/C/33/D/197/1985, para 6.3.

${ }^{5}$ The UNGA "Declaration on the Inadmissibility of Intervention in the Domestic Affairs of States and the Protection of Their Independence and Sovereignty", Res 2131 (21 Dec 1965), UN Doc A/RES/2131.

${ }^{6}$ Advisory opinion of ICJ in Legal Consequences of the Construction of a Wall in the Occupied Palestinian Territory, ICJ Rep 136, 172 (2004).

7 James Crawford, International Law Commission's Articles on State Responsibility: Introduction, Text and Commentary, Cambridge University press, (2002), p168.
} 
particular document was framed explicitly in the context of colonial peoples and territories, and takes the attitude that the passionate yearning for freedom in all dependent peoples and the decisive role of such peoples is "the attainment of their independence "" ${ }^{8}$ Rigo argues that: "right to self-determination has been the vehicle of choice for achieving decolonization". 9

Other important documents are ICCPR and ICESCR.

\section{B. ICCPR and ICESCR, (1966)}

In 1966, states have shown their willingness to set forth this right as a provision of law. As a result, under international law, RSD is recognized under two important human rights instruments, namely, ICCPR and ICESCR. Article 1 of both International Covenants recognizes inherent RSD of all the people worldwide. It states as follows:

a) All peoples have the right of self-determination. By virtue of that right they freely determine their political status and freely pursue their economic, social and cultural development.

b) All peoples may, for their own ends, freely dispose of their natural wealth and resources without prejudice to any obligations arising out of international economic cooperation, based upon the principle of mutual benefit, and international law. In no case may a people be deprived of its own means of subsistence.

c) The States Parties to the present Covenant, including those having responsibility for the administration of Non-Self-Governing and Trust Territories, shall promote the realization of the right of self-determination, and shall respect that right, in conformity with the provisions of the Charter of the United Nations.

It is described in initial paragraphs as inalienable right, which means that it is absolute and unchangeable or inherent. People may freely "determine their political status and freely pursue their economic, social and cultural development", by virtue of that right. The article enshrines protection and also imposes obligations on states. In terms of interpreting text of article 1, the committee on ICCPR has noted that states are reluctant to give explanation and provide inadequate information in terms of its implementation. The Committee has considered that states should provide information on each paragraph. Also States are obliged to elaborate constitutional and political process which put into effect this right. Paragraph two of the article relates to economic aspect of self-determination and affirms people's right to

\footnotetext{
${ }^{8}$ UNGA Resolution no: 1514 (XV), UN Doc. A/4684, (1961).

9 A. Rigo Sureda, The Evolution of the Principle of Self-determination: A Study of UN Practice, Sijthoff publishers, (1973).
} 
freely dispose of their natural wealth and resources without prejudice to any obligations arising out of international economic cooperation, based upon the principle of mutual benefit, and international law.

In no case may a people be deprived of its own means of subsistence", for their own ends. Under this paragraph, states are obliged to indicate contrary factors which prevent or impede the disposal of natural resources and wealth. For all states and the International community there are corresponding duties in relation to protection of this right. Also states are required to elaborate effect of this right for enjoyment of other rights set forth in Covenants. Paragraph three of the Covenant imposes specific obligations on states. It also includes those people who are deprived or in pursuit of or struggling for RSD. It states that: "The States Parties to the present Covenant, including those having responsibility for the administration of Non-Self-Governing and Trust Territories, shall promote the realization of the right of self-determination, and shall respect that right, in conformity with the provisions of the Charter of the United Nations".

This provision links to all entities which are neither state nor recognized and includes freedom fighters as well as occupied people. This provision requires states to take positive action for realization of right. Positive action negates interference in matters of other state which adversely affects the exercise of this right. States are required to take effective measures for implementing it. The committee on ICCPR has also noted that: "The history has proved that the realization of and respect for the right of self-determination of peoples contributes to the establishment of friendly relations and cooperation between States and to strengthening international peace and understanding". ${ }^{10}$ Thus the importance of this right cannot be ignored. Although RSD is enshrined in article 1 of ICCPR and ICESCR but it also links to other legal instruments, such as, the UN Charter, (1945), Declaration on Principles of International Law concerning Friendly Relations and Co-operation, (1970) and other International documents. ${ }^{11}$

The Declaration on the granting of independence to colonial countries and peoples, (1960)

The 1960 Declaration is the most important document in relation to selfdetermination. Salient features of the Declaration are as follows: (i) All people have the right to self-determination; (ii) The inadequacy of democratic institutions etc should not serve as a

${ }^{10}$ Article 1 of CCPR General Comment No. 12: The RSD of peoples, 13/03/84.CCPR, Twenty-first session, (1984).

${ }^{11}$ The UNGA adopted it on 24 October, (1970) through Resolution 2625 (XXV). 
pretext for delaying independence; (iii) The armed action or repressive measures against a people struggling for independence should cease, and the integrity of their national territory be respected; (iv) It declares that: "immediate steps should be taken in Non-Self Governing Territories to move them towards their independence"; (v) It states that: "attempts to disrupt partially or totally the territorial integrity of a state was incompatible with the purposes and principles of the UN Charter"; and (vi) All states would observe the Charter, the Universal Declaration and the principle of non-intervention in the internal affairs of another state.

It declares in express terms that:

Every State has a duty to promote, through joint or separate action, the realisation of the principle of equal rights and self-determination of peoples, in accordance with the provisions of the Charter, and to render assistance to the United Nations in carrying out the responsibilities entrusted to it by the Charter regarding the implementation of the principle in order: (a) to promote friendly relations and co-operation among States; and (b) To bring a speedy end to colonialism, having regard to the freely expressed will of the peoples concerned. ${ }^{12}$

\section{Declaration on Principles of International Law concerning Friendly Relations and Co- operation, (1970)}

Another important document for understanding self-determination as a Jus Cogens norm is the interpretation of the "Declaration on the Principles of International Law Concerning Friendly Relations and Co-operation among States in accordance with the Charter of the United Nations” ('1970 Declaration'). ${ }^{13}$

The 1970 Declaration accepts that "self-determination relates to the political status of a people. This is important and arguably is at odds with the findings of human rights monitoring bodies, which seek to introduce an element of 'internal' sovereignty that seeks to exclude the notion of political status, focusing instead on the virtues of equality and representation within a state". ${ }^{14}$ The Declaration also accepts that colonialism must be brought to a speedy end and calls upon states to act to further this end. In terms of entitlement of RSD Resolution 1541 (XV) outlines that: "an obligation [that] exists to transmit information under Article 73 (e) of the Charter in respect of such territories whose people have not yet attained full measure of self-government".

\footnotetext{
${ }^{12}$ The UNGA Resolution no: 2625 on "Declaration on Principles of International Law Concerning Friendly Relations and Co-operation Among States", 121,UN Doc.A/8028, (1970).

${ }^{13}$ Ibid;

${ }^{14}$ Committee on the Elimination of Racial Discrimination, General Recommendation XXI on selfdetermination, UN Doc. CERD/48/Misc.7/Rev.3 (1996).
} 
The other important international documents include the UN Resolutions, such as, the UNGA Resolution no: 1541 (XV) on defining three options for self-determination and the UNGA Resolution no: 1654 (XVI) for establishing "special committee on Decolonization". Other relevant documents are also there. However, the most important documents are ICCPR and the ICESCR which defines RSD under article 1. The HRC has noted that article 1 of ICCPR is relevant to internal self-determination. ${ }^{15}$ Despite legal framework on selfdetermination is clear, it is necessary to examine self-determination as custom or norm of Jus cogens and exercise of this right in oppression.

\section{Self-determination as a custom or "Norm of Jus Cogens"}

The concept of self-determination is part and parcel of custom having force of CIL. Various factors lead to crystalisation of this concept as custom. Custom is arguably generated by the UN Charter and article 1 of ICCPR and ICESCR, (1966). ${ }^{16}$ However, Custom signifies far reaching effects and scope as compared to these provisions.

The UNGA Resolutions have influenced and enhanced the scope of custom. For instance, as already noted down, on self-determination these two declarations are quite important which are part of CIL, such as, (i) the "'Declaration Granting Independence to Colonial Countries and Peoples; ${ }^{17}$ and (ii) the Declaration on Principles of International Law Concerning Friendly Relations and Cooperation among States in Accordance with the Charter of the UN. These declarations have influenced custom and created legal standards for selfdetermination. ${ }^{18}$ Alongwith the UN Resolution, the role of the ICJ is also significant for custom's development. The ICJ has discussed the principle of self-determination in various cases and focused on its importance as a custom. The ICJ considered self-determination as a customary norm. ${ }^{19}$ Example to that extent include the Case Concerning East Timor (Portugal $\mathrm{v}$ Australia), in which the ICJ has declared that self-determination is erga omnes obligation

\footnotetext{
${ }^{15}$ Committee on the Elimination of Racial Discrimination, General Recommendation XXI on selfdetermination, UN Doc. CERD/48/Misc.7/Rev.3 (1996).

${ }^{16}$ Antonio Cassese, Self-determination of Peoples, 39 Cambridge University press, (1995), p159.

${ }^{17}$ Resolution no: 1514 of (960), UN Doc A/RES/1514.

18 Declaration on Principles of International Law concerning Friendly Relations and Co-operation among States in Accordance with the Charter of the United Nations, the UNGA Res 2625 of 24 October, (1970), UN Doc A/Res/2625 (Resolution 2625).

19 Advisory opinion of ICJ in Western Sahara Case, (1975), ICJ Rep 12; and opinion in Legal Consequences for States of the Continued Presence of South Africa in Namibia, (1971), ICJ Rep 16.
} 
meaning thereby part of Customary International Law (CIL). This interpretation has strengthened and solidified the content of self-determination as custom. ${ }^{20}$

The Vienna Convention on the Law of Treaties states that: a "preemptory norm is a norm accepted and recognised by the international community of States as a whole". ${ }^{21}$ Many Scholars of the legal arena have considered self-determination as a "preemptory norm "or a "norm of Jus cogens". ${ }^{22}$ However, in practical terms, self-determination creates difficulties in terms of its universality because of its political nature and ambiguous character. Scholars have also discussed and considered it as a right. There seems difference of opinion among scholars for considering it as right or a "preemptory norm". Some argue that considering it as a right is inappropriate and incorrect because of its ambiguous character and complexity. ${ }^{23}$

Many socialist states have acknowledged and endorsed the validity of selfdetermination as a "norm of Jus Cogens". The UNGA has also shown its general acceptance through Resolutions and it is endorsement of international community as well. ${ }^{24}$ However some states diverse in this regard and do not consider this view in general but consider that "self-determination is fundamental principle of international community". ${ }^{25}$ However, resolutions of the UN Assembly and the ICJ strengthen the view that self-determination is a "preemptory norm". However, the recognition of RSD as preemptory norm can impact political legitimacy to breaches of this principle because preemptory norms have higher status under international law and within international community. ${ }^{26}$ The application of selfdetermination is dependent upon its breach but is complex.

\section{A. Oppression and Self-determination}

Self-determination has potential implications for political and territorial instability of states. In this context, states have seen universality of the concept of self-determination in nervousness. It has also implication for right to remedial secession and is complex. ${ }^{27}$ Josep argues that: "The legitimacy of a people's secession depends on whether this people have the

\footnotetext{
${ }^{20}$ Advisory opinion on Case Concerning East Timor (Portugal v Australia), (1995), ICJ Rep 90, 102.

${ }^{21}$ Article 53 of Vienna Convention on the Law of Treaties, (1969).

${ }^{22}$ Ian Brownlie, Principles of Public International Law, Oxford University press, (2003), p 489.

${ }^{23}$ Michael Pomerance, "Self-Determination in Law and Practice", Martinus Nijhoff Publishers, (1982), pp70-71.

${ }^{24}$ Ibid; at 139.

${ }^{25}$ Antonio Cassese, Self-determination of Peoples, 39 Cambridge University press, (1995), p137.

${ }^{26}$ Donald K. Anton, Penelope Mathew and Wayne Morgan, International Law: Cases and Materials, Oxford University press, (2005), p234.

27 Kathleen Mcvay, "Self-determination in new contexts: The Self-determination of Refugees and Forced Migrants in International law”, Igitur, Utrecht Publishing \& Archiving Services, Volume 2, (2012), p44.
} 
right to self-determination within their actual state. This is the interpretation of international law defended by the well-known ruling by the Supreme Court of Canada regarding the secession of Quebec". This ruling does not deny the condition of Quebecers being neither "a people nor their RSD". On the contrary, it concludes that the "Canadian constitutional system allows for the exercising of this right and therefore Quebec cannot invoke the RSD to secede unilaterally". ${ }^{28}$

However, history reveals that people struggle for their self-determination when oppressed. In particular, in the context of decolonization, oppressed people invoked for exercise of self-determination. The application of self-determination in this context is highly controversial. For instance, it is difficult in its application to forced migrants and refugees. The principle is linked with other factors in political and practical terms. The response from oppressed appears when there is breach of self-determination. Today, self-determination is more flourishing and emerging concept but since 1960 "not one of the major international instruments dealing with self-determination has limited its application to decolonization". ${ }^{29}$

Surprisingly, international concern has shifted away from exercise of selfdetermination from colonial context to the case of oppression and acknowledged by International community. This view is supported by the language of numerous international instruments and Resolutions. For instance, Resolution 2625, ${ }^{30}$ and African Charter. ${ }^{31}$ However, according to ICJ, self-determination is crystallised and integrated in CIL. ${ }^{32}$ The remedies available for breach of self-determination vary from case to case and differs. It also signifies that self-determination operates in unique way and as per circumstances of the case. In general, RSD of the people who are in oppression is recognized by international community by many times.

Examples include: (i) "non-white South Africans"; 33 (ii) the "people of Tibet"; 34 and most prominently, the "Palestinian people". ${ }^{35}$ From the preceding discussion, it appears that self-determination is regarded and recognized as right of oppressed people irrespective of its

28 Josep Costa, "Does Catalonia have the right of Self-determination?", Catalonia background information Series E / 2017 / 2.1 / EN, p3.

29 Robert Mccorquodale, "Self-Determination: A Human Rights Approach", The International and Comparative Law Quarterly, (1994), p867.

${ }^{30}$ The UNGA Resolution 2625 of (1970) UN Doc A/RES/2625.

31 Articles 5 and 20 of "African Charter on Human and Peoples' Rights", (1981).

32 The Walls's Case, para. 171.

${ }^{33}$ The UNGA Resolution 2625 (1970) UN Doc A/RES/2625.

34 The UNGA Resolution no: 1723 of 20 December, (1961) on question of Tibet, UN Doc A/Res/1723.

${ }^{35}$ Resolution no: 2787 of 6 December, (1971), UN Doc A/Res/2787. 
complex implications and various dimensions for its determination. The next section discusses human rights and self-determination in occupied territories.

\section{Self-determination and upholding human rights in occupied territories}

In occupied territories, the ides to protect human rights of occupied is accepted by states after inception of the UN and formulation of detailed human rights instruments. The actions of the occupying powers as well as occupied (if they act in resistance) is crucial to control. However, the idea to protect human rights is widely accepted. ${ }^{36}$ This idea is also acknowledged by the $\mathrm{UNGA}^{37}$ through Resolutions and by the UN HRC. ${ }^{38}$ Although the provisions of IHL also apply in times of armed conflict but in general, protection of human beings is a "primary concern of international community". The provisions of International human rights law (IHRL) apply in complementarily along with provisions of International law of occupation (ILOC) and International Humanitarian law (IHL). This view is also supported by the European Court for Human Rights (ECHR). ${ }^{39}$

For the protection of human rights in occupied territory, the occupying powers are under international legal obligations to "restore peace and security and maintain law and order". However, in some situations, it is difficult to determine which norm will apply. For instance, certain civil and political rights of people can be suspended during occupation but it does not mean that atrocities may be committed for achieving peace. There exist interplay in the provisions of ILOC and IHRL. It is argued that human rights of people during occupation must be protected by the occupying powers because their interests are recognized by international community in numerous documents. Similarly, the RSD also seeks attention for its protection by the occupying powers in practical terms.

Occupation is a complex situation whereby the interests of occupied are attached. However, certain documents included it among "the unlawful modalities of governance,

\footnotetext{
${ }^{36}$ Yoram Dinstein, "Human Rights in Armed Conflict: International Humanitarian Law", in "Theodor Meron, Human Rights in International Law: Lehal and policy Issues", 345, Oxford Scholarship online, (1986), pp350-52.

37 The UNGA Resolution no: 2675 (XXV) of 09 December, (1970) on Basic Principles for the Protection of Civilian Population in Armed Conflicts. The first basic principle for the protection of civilian population states: "Fundamental human rights, as accepted in international law and laid down in international instruments, continue to apply fully in situations of armed conflict".

${ }^{38}$ The Human Rights Committee's Concluding Observations concerning the Israeli report, 18/08/98

Online available at http://www1.umn.edu/humanrts/hrcommittee/israel1998.html. Also Eyal Benvenisti, "The Applicability of Human Rights Conventions to Israel and to the Occupied Territories", 26 Israel law Review, 24 (1992).

${ }^{39}$ Loizidou vs. Turkey 23 decided by the ECHR in (1996).
} 
similar to colonialism and apartheid". ${ }^{40}$ Kelly argues that "the various the UN-supported humanitarian interventions or peace-enforcement operations that took place since the 1990s (former Yugoslavia, Somalia, Haiti, Mozambique, Angola, Western Sahara, and East Timor) failed to recognize the applicability of the law of occupations", despite their focus on restoring and ensuring "public order and civil life". ${ }^{41}$ Adam Roberts also maintains that occupation is temporary phenomena and linked with other factors. However, protection of human rights is central and states and the occupying powers have obligations in this regard. ${ }^{42}$ However, most of the scholarly discussions are centered on the practices of Israel.

The concept of self-determination of occupied was floated and taken into consideration by states during the 1970s, when resistance in the occupied Palestinian territories against occupation of "West Bank and Gaza" by Israel was appeared. The struggle of Palestinians against occupation is recognized and considered as legitimate exercise of right to self-determination of the people of Palestine. The international community has recognized Palestine as occupied territory. The UNGA has also adopted Resolutions in the context of occupation. For instance, Section 2 of the UNGA Resolution 3171 (XXVIII) mentions and "[s]upports resolutely the efforts of the developing countries and of the peoples of the territories under colonial and racial domination and foreign occupation in their struggle to regain effective control over their natural resources." 43

Other international documents and Resolutions were also adopted in order to ensure protection by states and the occupying powers at all levels. For instance, The UNGA Resolution 3281 (XXIX) titled: "The Charter of Economic Rights and Duties of States, 12 December", (1974), ${ }^{44}$ provides that:

1. It is the right and duty of all States, individually and collectively, to eliminate colonialism, apartheid, racial discrimination, neo-colonialism and all forms of foreign aggression, occupation and domination, and the economic and social consequences thereof, as a prerequisite for development". "States which practice such coercive policies are economically responsible to the countries, territories and peoples affected, for the restitution and full compensation for the exploitation and depletion of, and damages to, the natural and

\footnotetext{
${ }^{40}$ Resolution no: 3314 (XXIX) of 14 December, (1974).

${ }^{41}$ Michael J. Kelly, Restoring and Maintaining Order in Complex Peace Operations: The Search for a legal framework, Brill, Martin Nijhoff Publishers, (1999).

42 Adam Roberts, "Prolonged Military Occupation: The Israeli-Occupied Territories since 1967", 84 AJIL 44 (1990), p73.

${ }^{43}$ The UN Doc. A19400 of 17 December, (1973).

${ }^{44}$ Article 16(1) of the UNGA Resolution no: 3281 (XXIX) of 12 December, (1974).
} 
all other resources of those countries, territories and peoples. It is the duty of all States to extend assistance to them.

2. No State has the right to promote or encourage investments that may constitute an obstacle to the liberation of a territory occupied by force.

Similar references in relation to occupation are found in Article I (4) of the AP-I, (1977) and the "International Convention against the Taking of Hostages", (1979). ${ }^{45}$ Thus it appears that states are under obligation to avoid colonialism and apartheid. These obligations also extend to the occupying forces. Occupation is a temporary phenomenon which must be avoided by states. In prolonged occupations, the occupying powers have more humanitarian and human rights obligations which include protection of RSD of the people. The obligations are classified by the ICJ in its 2004 Advisory opinion on the legality of construction of Wall in occupied Palestine territories. The question is that what if provision of self-determination is breached or violated?

\section{A. Do states use force in violation or breach of self-determination?}

In general, under the UN Charter, it is recognized that force can be used only in exceptional circumstances and after fulfilling the criteria established by the Charter under Article 2(4). It also extends to the case of occupation. In occupied territories, the occupying powers have also this obligation and they are required to administer that territory according to the norms of international law. The RSD of people in occupied territories cannot be denied because it is also recognized by the International community.

This recognition also prohibits "use of force" by states against other states or by the occupying powers against occupied or civilians. In this context, there is prohibition on use of force by states to reject RSD of people. This principle is expressed in international instruments. For instance, the UNGA Resolution no: $2625,{ }^{46}$ Resolution no: $3314^{47}$ and Resolution no: $1514 .^{48}$ Along with these provisions, the ICJ has also acknowledged and solidified its authenticity. ${ }^{49}$ It is also protected by article 2(4) of the UN Charter. The "use of force" for denying self-determination leads to violence or threat to violence by states.

The "use of force may breach self-determination by either undermining the ability of a peoples to exist (for example through acts of genocide), or by compromising a peoples'

${ }^{45}$ UN Doc. AlC.6/34/L.23.

${ }^{46}$ Resolution no: 2625 of (1970) UN Doc A/RES/2625.

${ }^{47}$ Resolution no: 3314 of (1974) UN Doc A/RES/3314, art 7.

${ }^{48}$ Resolution no: 1514 of (1960) UN Doc A/RES/1514.

49 Advisory opinion of ICJ in "Armed Activities on the Territory of the Congo (DRC v Uganda)", (2005), ICJ Rep 168, 182. Also The Wall's Case, para.172 
ability to access government through violence or threat of violence". The denial of that right may also lead to destruction carried out by people as response. In complex cases of occupation, it is need of the hour to control actions of the occupying powers in practical terms because the RSD of the people concerned cannot be denied. It would also be useful for promotion and protection of their rights. This discussion leads to converse that who is entitled for self-determination. The next section analyses this issue by referring legal framework of self-determination.

\section{Who is entitled to exercise right to self-determination?}

Although international instruments recognized RSD in express terms, such as, the ICCPR and the ICESCR. However, the question is that who is entitled to exercise a RSD? It is crucial to determine because the wording is somewhat ambiguous in terms of its availability to colonial people only or it extends to 'all' ${ }^{50}$ On the other hand, the bulk of IHRL protects rights of 'everyone'. There is need to clarify its status by taking into consideration different views and interpretations.

In general, one view is that RSD is not available to all and not everyone is entitled to this right inherently. In 1986, on reporting "Aboriginal Customary law", the "Australian Law Reform Commission" (ALRC) has elaborated certain dimensions of self-determination. The Commission has stated that: "Advocates for ethnic, indigenous or linguistic minorities sometimes rely upon the principle or right of self-determination in international law as a basis for claims to political or legal recognition. So far however, the principle has been confined in international practice to situations involving separate ('colonial') territories politically and legally subordinate to an administering power". ${ }^{51}$

Thus according to commission of Australia, the RSD is only available to colonial people. Similarly, some scholars of the legal arena argue that RSD is limited and available only to colonized people. No other category of people falls for enjoyment of this right. They support their argument with the UNGA's Resolution no: 1514, which is first document which comprehensively deals with self-determination. They hold that this limitation is beneficial for international harmony and exercise of self-determination within boundaries is advantageous.

\footnotetext{
${ }^{50}$ It is endorsed by the UN Resolutions and international instruments that right to self-determination is available to all.

${ }^{51}$ A.L.R.C., Report of ALRC No: 31 titled: "Recognition of Aboriginal Customary Law", 128 (1986).
} 
Under this view, ethnic minorities who have not definite colonial boundaries do not exercise RSD and many claims would fail. ${ }^{52}$

However, in light of this claim, there exists uncertainty because practices are different. For instance, the claims of Macedonia ${ }^{53}$ against Yugoslavia; claim of people of Soviet Union ${ }^{54}$ against Moscow; claims by Bouganville claim against Papua New Guinea; ${ }^{55}$ claims by the Serbian minority of Krajina against Croatia; ${ }^{56}$ claims by Slovenia ${ }^{57}$ and Croatia. ${ }^{58}$ This view is limited and in terms of those who are struggling for liberation or against occupation is questionable.

Another practices shows that, some states have accepted RSD as a principle of international law. However, RSD is not based merely on political philosophies rather it has various dimensions in different regions. ${ }^{59}$ The essence lies in international practice for protection of self-determination. ${ }^{60}$ The important consideration for exercise of selfdetermination is aspirations or wishes of the people concerned. For instance, in 1971, Bangladesh was separated from Pakistan on the basis of wishes of the people and now it is considered as separate State. Bangladesh has won its independence by strength of its people. ${ }^{61}$ The struggle for RSD is significant for resolution. In this context, another example is of Ruanda and Burundi which gained independence in 1962. The UNGA has declared to form one state but due to wishes of the people both were separated.

These States lie in Africa between Tanzania and Zaire. ${ }^{62}$ Thus it is argued that selfdetermination must be implemented and enforced in essence particular in the case of occupation. The people struggling against occupation also fall under the ambit of 'everyone' and seek attention. It is responsibility of international community to consider efforts of such

52 James R. Crawford, The Creation of States at International Law, Oxford University press, (1979), pp91-93.

53 The Age, 29 April, (1991).

${ }^{54}$ Report by Elizabeth Shogren, Soviet Georgians Flock to Polls to Vote for Secession, L.A. Times, 1st April, (1991).

55 Report of The Australian of 04 September, (1990).

${ }^{56}$ Report of The Age of 29 April, (1991).

57 Ibid;

${ }^{58}$ Report of The Age of 31 May, (1991).

${ }^{59}$ Oji Umozurike, Self-determination in international law, 3 Archon Books, (1972), p179.

${ }^{60} \mathrm{~W}$. Ofuatey-kodjoe, The principle of Self-determination in International Law, 183 Nellen pub comp Itd, (1977), p51.

61 Ibid; at p144.

62 The UNGA Resolution no: 1579, U.N. Doc. A/4684, 35, (1960); and UNGA Resolution no: 1605, U.N. Doc. A/4684/Add. 1. 
struggle or liberation movements in order to "maintain peace and security" worldwide and for the sake of humanity.

On the other hand, various Scholars argue that RSD is not limited to colonial context rather it extend to 'everyone, and available to all. For instance, Collins maintains that: "although political events have concentrated the UN's focus on colonial territories and the UN stands firm on the concept of territorial integrity, the principle of self-determination should not be considered strictly as a colonial right" ${ }^{63}$ The entitlement of this right is also advance by Nanda. ${ }^{64}$ They supported their views on the wording of the UN Charter and the UNGA Resolutions. However, this view is controversial. There is inconsistency between these two approaches. ${ }^{65}$ However, it is a big challenge to ensure implementation of RSD in practical terms. On the basis of these views, it can be argued that more accurate and preferable claim is last one because RSD may also extend to minority groups, people struggling for their independence and non-state entities (NSEs).

It is well established that human rights are available to 'everyone' on the basis of humanity. Thus it is argued that the RSD may be available to 'everyone' and extended to those who have been denied. In Israel-Palestine case, the Palestinians have RSD which needs backing and implementation by international community. Similarly, the case of State of Jammu and Kashmir $(\mathrm{J} \& \mathrm{~K})$ is quite significant in this respect that needs special attention for its solution. Kashmiris are struggling for achievement of RSD as promised by the UN. It is need of the hour that the people of J\& K may be given protection of RSD in all means and through Plebiscite. The resolution of Kashmir dispute may be resolved under auspices of the UN in line with demands and wishes of the people of Kashmir. It is also necessary for securing purposes of the UN. In terms of RSD, it is argued that it is necessary and inevitable to enforce and implement RSD in Occupied Palestine territory and the State of J \& K by peaceful means. The International community should take realistic, practical, functional and humanitarian measures in order to resolve disputes in peaceful ways. Otherwise the applicability of the norms of international law for protection of 'everyone' is vague and endangered for "International peace and security".

${ }^{63}$ John A. Collins, "Self Determination in International Law: The Palestinians", Case Western Reserve Journal of International Law, 137, 138 (1980), p153.

${ }^{64}$ Ved P. Nanda, "Self-Determination Under International Law: Validity of Claims to Secede", Case Western Reserve Journal of International Law, 257, 266 (1981).

${ }^{65}$ Deborah Z. Cass, "Re-thinking Self-determination: A critical analysis of current international law theories", Surface, Syracuse Journal of International Law and Commerce, Vol. 18, No: 1, (1992), p11. 


\section{Conclusion}

From the preceding discussion, it is concluded that RSD is universally recognized right. It is enshrined in many international documents. The most important documents are provisions of the UN Charter, the ICCPR and the ICESCR. Other documents also clarify its availability to all. The nature and scope of RSD is different as compared to other rights. However, it is not dependent on the existence of other rights.

The bulk of IHRL's instruments recognize human rights of all people worldwide without distinction and discrimination. The legal framework of self-determination includes the UN Charter, the ICCPR and the ICESCR, the UN Declarations and Resolutions. For understanding its validity under international law, the most important thing for consideration is the judgment of ICJ in Legal consequences of Construction of Wall in occupied territories delivered 2004. The judgment has recognized RSD of Palestinis in the context of IsraelPalestine conflict. However, it is argued that such recognition and implementation of this right may also be extended to the State of J\&K where future status of people are yet to be determined. Although the plebiscite is promised by the UN through adoption of Resolutions but it is need of the hour to take practical steps in order to resolve Kashmir dispute which is central to Pakistan and India.

The people in oppression also possess RSD subject to the norms of international law. In terms of occupied territories, the RSD is recognized but has complexities in relation to enforcement and implementation. For instance, the RSD of Kashmiris who are struggling for achievement of this right since decades. It is need of the hour to protect dignity, selfdetermination and basic human rights of Kashmiris.

Such protection will lead to provide them space in the modern world because thousand Kashmiris have been martyred, killed, burnt and atrocities have been committed because of their struggle for self-determination. In the case of violation of RSD, it is argued that people may be punished accordingly but snatching of this right is inconsistent with the primary purposes of the $\mathrm{UN}$ and is violation of the whole bulk of international law. Entitlement of RSD is not limited to colonized countries rather it extends to those who are struggling for their independence and liberation. It is need of the hour to protect RSD of peoples at all levels and by all means in order to secure peace worldwide. The international community has to play an important role for ensuring protection and enforcement of RSD to 'everyone' at all levels and by all necessary means. 